\title{
SYNTHESIS AND DNA-BINDING STUDIES OF NOVEL 2-NITRO ACRIDONES AS ANTI-CANCER AGENTS
}

\author{
KR. Chaithra, NK. Sathish* and KP. Channabasavaraj \\ Medicinal Chemistry research division, Government College of Pharmacy, \\ Bengaluru-560 027, Karnataka, India.
}

\section{ABSTRACT}

A series of novel $\mathrm{N}^{10}$-substituted 2-nitro acridones were synthesized as potent anti-tumor agents. DNAbinding studies of these compounds were carried out by UV spectroscopy using Calf thymus DNA (CT DNA) based on their affinity or intercalation with CT-DNA measured with absorption titration. The binding constants were determined at the range of $\mathrm{K}=0.49-1.92 \times 10 \mathrm{M}^{-1}$ and the percentage of hypochromicity was calculated using absorption values ranges from 30-71.26\%. The compound 7 bearing nitro group with planar tricyclic ring linked to butyl morpholine side chain showed highest binding affinity with binding constant $1.92 \times 10 \times \mathrm{M}^{-1}$ and with lipophilicity value of 3.30-3.74. The compound 6 showed high lipophilicity value. The examination of the relationship between lipophilicity and binding ability of the acridones showed poor correlation.

Keywords: 2-Nitroacridone, DNA-binding, Calf-Thymus DNA, UV spectroscopy and Lipophilicity.

\section{INTRODUCTION}

The attractive target for the design of new antitumor agents was DNA. There is a considerable interest taken in the development of new drugs with low molecular weight to bind with DNA towards their application in cancer treatment ${ }^{1}$. Understanding of the structural and thermodynamic aspects of the interactions between the drug and the DNA helps in designing the potential anti-cancer agents. It has been found that many cytostatic drugs interacts with DNA by different ways a) Intercalation or through minor groove binding b) Cross linking or combination of these modalities. $^{2}$

A drug molecule is acting against cancer means it has the ability to reach target site and specific to cancer cell, capable of binding to multiple targets might be beneficial and may also prevent in acquiring drug resistance. ${ }^{7,10}$ Several structural classes of compounds were discovered aganist tumour involves alkylating agents, anti-metabolites, microtubule damaging agents, topoisomerase-2 inhibitors, topoisomerase-1 inhibitors, antibiotics, anthracenediones, harmones and miscellaneous drugs. Planar molecules with tricyclic structures were reported to possess significant cytotoxic and cytostatic potencies, mainly by DNA interaction. In the year 1960s, Lerman by conducting a number of physical studies concluded that large number planar aromatic polycyclic molecules binds to the DNA by the process of intercalation ${ }^{1}$. It may include Anthraquinones, acridines and Xanthenes.

The first broad spectrum natural anti-cancer agent which was discovered by random screening was doxorubicin despite of its several cardiotoxicity. The first DNAintercalating agent widely used as an anticancer agent was Actinomycin-D, which entered clinical use in 1960's.

There are numerous biologically active fused heterocyclic rings. Among these acridones are the interesting heterocyclic compounds to medicinal chemist as they exhibits a wide range biological activitiy. The acridone alkaloid Acronycine also known as Acronine was first isolated from the bark of Australian tree Acronychia baurri in 1948 and found that it showed potent activity against cancer.

Acridone is a versatile heterocyclic structure having a unique chemical properties like planar structure which exists in both protonated and unprotonated forms. It has the 
ability to intercalate with DNA and also as a substrate to $\mathrm{p}$-glycoprotein which was one of the essential target for multidrug resistance in cancer. The ideal and unique properties of acridones has drawn the attention of medicinal chemists and few of acridone derivatives are under clinical trials. ${ }^{13}$

Literature survey revealed that sathish NK et al. synthesized 1,3-dimethyl acridones ${ }^{14}$ and 1,3-diacetoxy acridones ${ }^{16}$, and their DNAbinding studies were carried out by absorption titration using CT-DNA. The compounds with acetoxy groups showed good binding properties compared to methyl groups. In 2008 Jinghua Chen et al. carried out the synthesis and DNA binding studies of 2-nitro acridone (NAD) using salmon sperm DNA by electrochemical method. The compound NAD showed good binding property with DNA. This showed that electron withdrawing groups attached to acridone nucleus helps in improving binding ability of acridones towards DNA.

Keeping these importance of acridones scaffolds, an effective anticancer which is specific to cancer cell, capable of binding multiple targets and devoid of acquiring drug resistance needs to be synthesized. However, the literature survey revealed that various acridones are reported to possess anticancer and anti-MDR activities, it was believed that the anticancer activity is due to their DNA intercalation property. ${ }^{16}$ DNA binding studies helps to determine the binding ability of different derivatives towards DNA. Higher the binding ability more will be the cytotoxicity of drug. In the present study an attempt was made to design and synthesize newer series of $\mathrm{N}^{10}$-substituted acridones for their DNAbinding properties and Lipophilicity.

\section{MATERIALS AND METHODS}

\section{Chemistry}<smiles>O=C(O)c1ccccc1Cl</smiles>
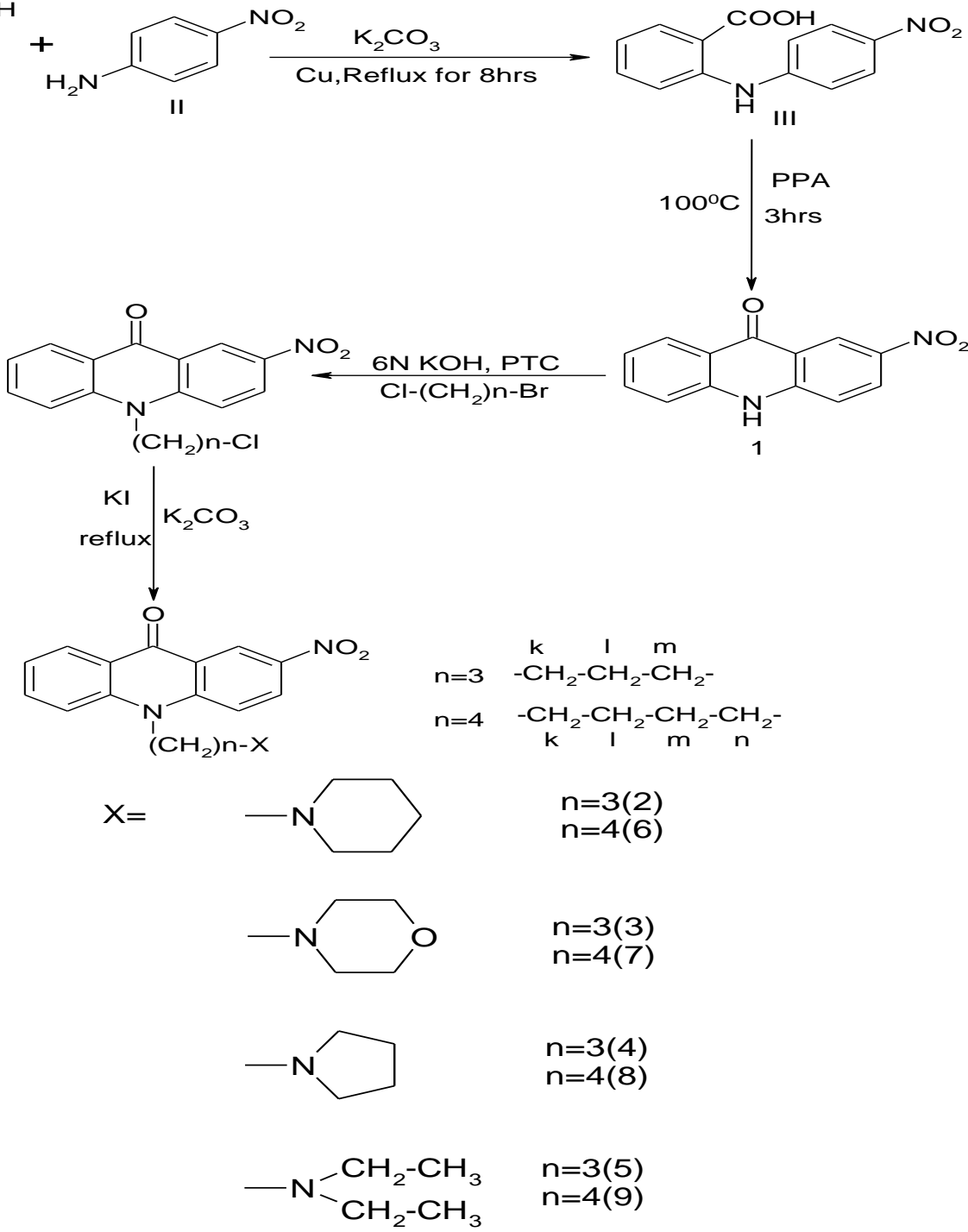

Scheme. 1: 


\section{Scheme 1}

2-Nitroacridone(1) and its derivatives 2-9 were synthesized by the scheme-1, parent 2-nitroacridone (1) was synthesized by the Ulmann condensation reaction of o-chloro benzoic acid and 4-nitro aniline to 4'nitrodiphenylamine-2-carboxylicacid (III). The 4'-nitrodiphenylamine-2-carboxylic acid (III) was cyclized with polyphosphoric acid instead of sulfuric acid on water bath at $100^{\circ} \mathrm{C}$ to get only single product of 2-nitroacridone (1) with better yield (95\%) was obtained.

$\mathrm{N}$-alkylation of the 2-nitroacridone was achieved by using Phase transfer catalyst (PTC) because nitrogen atom of the acridone nucleus is generally resistant to undergo $\mathrm{N}$ alkylation with alkyl halides due to their weakly basic in nature. Stirring of 2-nitroacridone (1) at room temperature with alkylating agents 1 bromo-3-chloro propane or 1-bromo-4-chloro butane in a two phase system consisting of an organic solvent (tetrahydrofuran) and $6 \mathrm{~N}$ aqueous potassium hydroxide solution in the presence of tetra butyl ammonium bromide (PTC) to synthesize the compounds 10-(3'chloropropyl)-2-nitroacridone and 10-(4'chlorobutyl)-2-nitroacridone respectively in good yields. Here, catalyst (PTC) transports the $\mathrm{OH}^{-}$ion from the aqueous phase to organic phase where actual reaction takes place. The ion formed may be regarded as phenolate stabilized anion, which subsequently undergoes alkylation to form the aromatized system.

lodide catalyzed nucleophilic substitution reaction of the $N^{10}$-chloropropyl or $N^{10}$-chlorobutyl 2-nitroacridone is carried out with various secondary amines (piperidine, morpholine, pyrrolidine, diethyl amine) by refluxing for different time intervals in the presence of anhydrous potassium carbonate in acetonitrile gave the free bases 2-5 and 6-9.

All the molecules were separated and purified by recrystallization method and dried under high vacuum for more than $12 \mathrm{~h}$. The purified compounds were characterized by ${ }^{1} \mathrm{H}-\mathrm{NMR}$ and mass spectral methods. The assignment of protons is fully supported by the integration curves and all the derivatives showed the characteristic chemical shifts for the acridone nucleus.

\section{Experimental Section}

Reactions were monitered by TLC. Melting points were recorded using thiele's tube apparatus. ${ }^{1} \mathrm{H}-\mathrm{NMR}$ were recorded in DMSO and $\mathrm{D}_{2} \mathrm{O}$ in a $5-\mathrm{mm}$ tube on a Bruker drx 500 Fourier transform spectrometer with tetramethylsilane as internal standard.
Chemical shifts are expressed as $\delta$ (ppm) values. The spectrometer were internally locked to deuterium frequency of the solvent. To obtain the molecular weight information, acridone derivatives were analysed by LC-MS spectrometry. DNA-binding studies of the synthesized compounds were performed by UV Sectrophotometer.

\section{Synthesis of 4'-nitro diphenylamine-2- carboxylic Acid Ullmann Condensation}

To a mixture of o-chlorobenzoic acid $(5 \mathrm{~g}$, $0.032 \mathrm{~mol})$, 4-nitroaniline $(4.416 \mathrm{~g}, 0.032 \mathrm{~mol})$ and copper powder $(0.2 \mathrm{~g})$ in $30 \mathrm{ml}$ isoamylalcohol, anhydrous potassium carbonate $(5 \mathrm{~g})$ was slowly added and the contents were allowed to reflux for $8 \mathrm{~h}$ on an oil bath. The isoamylalcohol was removed by steam distillation and the mixture poured into 1 lit of hot water and acidified with concentrated hydrochloric acid. Precipitate formed was filtered, washed with hot water and collected. The crude acid was dissolved in aqueous sodium hydroxide solution, boiled in the presence of activated charcoal and filtered. On acidification of the filtrate with concentrated hydrochloric acid, precipitate was obtained which was washed with hot water and recrystallized from methanol to give a yellow solid (yield $85 \%$ ), m.p. $180-185^{\circ} \mathrm{C}$.

\section{Synthesis of 2-nitroacridone (1)}

Five grams of 4'-nitrodiphenylamine-2carboxylic acid was taken in a flask to which was added $50 \mathrm{~g}$ of polyphosphoric acid. Shaken well and heated on a water bath at $100{ }^{\circ} \mathrm{C}$ for $4 \mathrm{~h}$. Appearance of yellow color indicated the completion of the reaction. Then, it was poured into 1 lit of hot water and made alkaline by liquor ammonia and the yellow precipitate formed was filtered, washed with hot water and collected. The sample of 2-nitro $9(10-\mathrm{H})$ acridone (1) was recrystallized from acetic acid (yield $95 \%$ ). M.p. above $300^{\circ} \mathrm{C}$

\section{2-nitroacridone (1)}

Yield: $60 \%$, M.p. Above $300^{\circ} \mathrm{C}$. $1 \mathrm{H}$ NMR $\left(\mathrm{CDCl}_{3}\right) \delta=7.37-8.9(\mathrm{~m}, 7 \mathrm{H}, \mathrm{Ar}-\mathrm{H}), 12.4(\mathrm{~s}, 1 \mathrm{H}$, cyclic $\mathrm{NH}) ; \mathrm{MS} \mathrm{m} / \mathrm{z}: 241.029\left(\mathrm{M}^{+}\right)$.

\section{Synthesis of $\mathrm{N}^{10}$-alkylated Acridones via Phase Transfer Catalysis \\ General method for the Synthesis of 10- (Chloroalkyl)-2-nitroacridone}

One gram (0.0042 mol) of 2-nitroacridone(1) was dissolved in $25 \mathrm{~mL}$ tetrahydrofuran and $17.5 \mathrm{ml}$ of $6 \mathrm{~N}$ potassium hydroxide and $0.43 \mathrm{~g}$ $(0.0013 \mathrm{~mol})$ of tetrabutylammonium bromide 
was added to it. The reaction mixture was stirred at room temperature for $30 \mathrm{~min}$ and added 1-bromo-3chloropropane $(0.013 \mathrm{~mol}) / 1$ bromo-4-chlorobutane $(0.013 \mathrm{~mol})$ slowly into the reaction mixture and stirred for $24 \mathrm{~h}$ at room temperature. Tetrahydrofuran was evaporated and the aqueous layer was extracted with chloroform. The chloroform layer was washed with water and organic layer dried over anhydrous sodium sulfate and rotavaporated. The crude product was purified by column chromatography by using the solvent system chloroform/ acetone (8:1) to give a yellow solid of 10-(chloroalkyl)-2nitroacridone (yield 50\%).

\section{0-(3'-chloropropyl)-2-nitroacridone}

Yield:52\%, $1 \mathrm{H}$ NMR $\left(\mathrm{CDCl}_{3}\right) \delta=7.4-8.6(\mathrm{~m}, 7 \mathrm{H}$, Ar-H), 2.1(m, 2H, $\left.\mathrm{H}_{\mathrm{l}}\right), 3.8\left(\mathrm{t}, 2 \mathrm{H}, \mathrm{H}_{\mathrm{k}}\right), 3.4(\mathrm{t}, 2 \mathrm{H}$, $\left.\mathrm{H}_{\mathrm{m}}\right) ; \mathrm{MS} \mathrm{m} / \mathrm{z}: 317.7\left(\mathrm{M}^{+}\right)$.

\section{0-(4'-chlorobutyl)-2-nitroacridone}

Yield:50\%, $1 \mathrm{H}$ NMR $\left(\mathrm{CDCl}_{3}\right) \delta=7.2-8.7(\mathrm{~m}, 7 \mathrm{H}$, Ar- $\mathrm{H}), 2.1\left(\mathrm{~m}, 2 \mathrm{H}, \mathrm{H}_{\mathrm{l}}\right), 3.52\left(\mathrm{t}, 2 \mathrm{H}, \mathrm{H}_{\mathrm{k}}\right), 4.11(\mathrm{t}$, $\left.2 \mathrm{H}, \mathrm{H}_{\mathrm{n}}\right), 1.5-2.26\left(\mathrm{~m}, 4 \mathrm{H}, \mathrm{H}_{1}\right.$ and $\left.\mathrm{H}_{\mathrm{m}}\right)$

General method for the synthesis of derivatives.(2-9)

10-(chloroalkyl)-2-nitroacridone $0.005 \mathrm{~mol}$ was dissolved in $60 \mathrm{ml}$ of anhydrous acetonitrile and $1.68 \mathrm{~g}$ potassium iodide and $3.3 \mathrm{~g}$ of potassium carbonate were added and refluxed for $30 \mathrm{~min}$. Added $0.009 \mathrm{~mol}$ of different secondary amines into it slowly and refluxed for $15 \mathrm{~h}$ until a substantial amount of the product was formed as evidenced by TLC. The contents were cooled, diluted with water and extracted with chloroform. The chloroform layer was washed with water thrice, dried over anhydrous sodium sulfate and evaporated to give product. An acetone solution of the free base was treated with ethereal hydrochloride to give the hydrochloride salt, which was dried over high vacuum to get pure solid.

\section{0-[3 ${ }^{1}$-N-piperidino propyl]-2-nitroacridone}

(2)

Yield: $50 \%$, M.p. $260^{\circ} \mathrm{C} .{ }^{1} \mathrm{H}$ NMR (DMSO) $\delta=7-$ 8.2(m, 7H, Ar-H), 3.2-4.2(m, 8H, $\mathrm{H}_{\mathrm{a}}, \mathrm{H}_{\mathrm{b}}, \mathrm{H}_{\mathrm{k}}$, $\left.\mathrm{H}_{\mathrm{m}}\right)$, 1.4-2.8(m, $\left.8 \mathrm{H}, \mathrm{H}_{\mathrm{l}}, \mathrm{H}_{\mathrm{c}}, \mathrm{H}_{\mathrm{d}}, \mathrm{H}_{\mathrm{e}}\right)$; MS m/z: $366.05\left(\mathrm{M}^{+}\right)$

\section{0-[3 ${ }^{1}$-N-morpholino}

nitroacridone (3)

Yield: $45 \%, 200^{\circ} \mathrm{C}$. $1 \mathrm{H}$ NMR(DMSO) $\delta=7.4-$ 9(m, 7H, Ar-H), 3.3-4.5(m, 8H, $\left.\mathrm{H}_{\mathrm{a}}, \mathrm{H}_{\mathrm{b}}, \mathrm{H}_{\mathrm{k}}, \mathrm{H}_{\mathrm{m}}\right)$, $3.6\left(\mathrm{~d}, 4 \mathrm{H}, \mathrm{H}_{\mathrm{c}}, \mathrm{H}_{\mathrm{d}}\right), 2.5\left(\mathrm{~m}, 2 \mathrm{H}, \mathrm{H}_{\mathrm{l}}\right) ; \mathrm{MS} \mathrm{m} / \mathrm{z}$ : $368.1\left(\mathrm{M}^{+}\right)$
10-[ $3^{1}-\mathrm{N}$-pyrrolidino nitroacridone (4)

amino

propyl]-2Yield: $40 \%,{ }^{1} \mathrm{H}$ NMR(DMSO) $\delta=7.2-8.5(\mathrm{~m}, 7 \mathrm{H}$, Ar-H), 3.3-4.7(m, 8H, $\left.\mathrm{H}_{\mathrm{k}}, \mathrm{H}_{\mathrm{m}}, \mathrm{H}_{\mathrm{a}}, \mathrm{H}_{\mathrm{b}}\right), 3.2(\mathrm{~d}$, $\left.4 \mathrm{H}, \mathrm{H}_{\mathrm{c}}, \mathrm{H}_{\mathrm{d}}\right), 1.7\left(\mathrm{M}, \mathrm{H}_{\mathrm{l}}\right) ; \mathrm{MS} \mathrm{m} / \mathrm{z}: 352.3\left(\mathrm{M}^{+}\right)$

\section{0-[3 ${ }^{1}$-N-diethyl amino propyl]-2- nitroacridone (5) \\ Yield: $40 \%,{ }^{1} \mathrm{H}$ NMR(DMSO) $\delta=6.8-8(\mathrm{~m}, 7 \mathrm{H}$,} Ar- $\mathrm{H}), 3-4.5\left(\mathrm{~m}, 8 \mathrm{H}, \mathrm{H}_{\mathrm{k}}, \mathrm{H}_{\mathrm{m}}, \mathrm{H}_{\mathrm{a}}, \mathrm{H}_{\mathrm{b}}\right), 2.2(\mathrm{t}, 2 \mathrm{H}$, $\left.\mathrm{H}_{\mathrm{c}}, \mathrm{H}_{\mathrm{d}}\right), 1.8\left(\mathrm{M}, \mathrm{H}_{\mathrm{l}}\right) ; \mathrm{MS} \mathrm{m} / \mathrm{z}: 354.12\left(\mathrm{M}^{+}\right)$

\section{0-(4'-N-Piperidinobutyl)-2-nitroacridone}

(6)

Yield: $50 \%$, M.p. $250^{\circ} \mathrm{C} .{ }^{1} \mathrm{H}$ NMR (DMSO) $\delta=7.2-8.5(\mathrm{~m}, 7 \mathrm{H}, \mathrm{Ar}-\mathrm{H}), 3.2-4\left(\mathrm{~m}, 10 \mathrm{H}, \mathrm{H}_{\mathrm{a}}, \mathrm{H}_{\mathrm{b}}\right.$, $\left.\mathrm{H}_{\mathrm{c}}, \mathrm{H}_{\mathrm{d}}, \mathrm{H}_{\mathrm{k}}, \mathrm{H}_{\mathrm{n}}\right), 1.8-2.8\left(\mathrm{~m}, 4 \mathrm{H}, \mathrm{H}_{\mathrm{l}}, \mathrm{H}_{\mathrm{m}}\right), 3.4(\mathrm{~m}$, $\left.\mathrm{H}_{\mathrm{e}}\right), ; \mathrm{MS} \mathrm{m} / \mathrm{z}: 380.17\left(\mathrm{M}^{+}\right)$

\section{0-[4 ${ }^{1}$-N-morpholino butyl]-2-nitroacridone} (7)

Yield: $40 \%, 195^{\circ} \mathrm{C} .1 \mathrm{H}$ NMR(DMSO) $\delta=6.4-$ 8.6(m,7H, Ar- $\mathrm{H}), 3.3-4.5\left(\mathrm{~m}, 8 \mathrm{H}, \mathrm{H}_{\mathrm{a}}, \mathrm{H}_{\mathrm{b}}, \mathrm{H}_{\mathrm{k}}\right.$, $\left.\mathrm{H}_{\mathrm{n}}\right)$, 3.6(t, $\left.4 \mathrm{H}, \mathrm{H}_{\mathrm{c}}, \mathrm{H}_{\mathrm{d}}\right), 1.5-2.8\left(\mathrm{~m}, 4 \mathrm{H}, \mathrm{H}_{\mathrm{l}}, \mathrm{H}_{\mathrm{m}}\right)$; MS m/z: $382.15\left(\mathrm{M}^{+}\right)$

\section{0-(4 ${ }^{1}$-N-Pyrrolidinobutyl)-2-nitroacridone}

(8) Yield: $40 \%$, M.p. $160^{\circ} \mathrm{C},{ }^{1} \mathrm{H}$ NMR(DMSO) $\delta=7.2-8.5(\mathrm{~m}, 7 \mathrm{H}, \mathrm{Ar}-\mathrm{H}), 3-4.6\left(\mathrm{dm}, 8 \mathrm{H}, \mathrm{H}_{\mathrm{a}}, \mathrm{H}_{\mathrm{b}}\right.$, $\left.\mathrm{H}_{\mathrm{k}}, \mathrm{H}_{\mathrm{n}}\right), 1.5-2.8\left(\mathrm{~m}, 8 \mathrm{H}, \mathrm{H}_{\mathrm{c}}, \mathrm{H}_{\mathrm{d}}, \mathrm{H}_{\mathrm{l}}, \mathrm{H}_{\mathrm{m}}\right) ; \mathrm{MS}$ $\mathrm{m} / \mathrm{z}: 366.16\left(\mathrm{M}^{+}\right)$

\section{0-[3-(N-Diethylaminobutyl)]-2-}

methylacridone (9)

Yield: $40 \%,{ }^{1} \mathrm{H}$ NMR(DMSO) $\delta=7-8.2(\mathrm{~m}, 7 \mathrm{H}$, Ar-H), 4.5(t, 2H, $\left.\mathrm{H}_{\mathrm{k}}\right), 3.2\left(\mathrm{~m}, 6 \mathrm{H}, \mathrm{H}_{\mathrm{a}}, \mathrm{H}_{\mathrm{b}}, \mathrm{H}_{\mathrm{n}}\right)$, $1.9\left(\mathrm{~m}, 4 \mathrm{H}, \mathrm{H}_{1}, \mathrm{H}_{\mathrm{m}}\right) ; \mathrm{MS} \mathrm{m} / \mathrm{z}: 368.14\left(\mathrm{M}^{+}\right)$

\section{RESULTS AND DISCUSSIONS BIOLOGICAL ACTIVITY \\ Lipophilicity}

The compounds lipophilicity was determined using the software ALOGPS. The efficacy of a cytotoxic drug will depend in part on its ability to accumulate in cells.. The efficiency of cytotoxicity mainly concentrates on accumulation of drugs within the cells. This helps in predicting the potency of drug. The acridone derivatives are weak bases and able to exist in both charged (protonated) and uncharged (unprotonated) forms. The lipophilicity data varying from 2.92-4.62, expressed in $\log _{10} P$, are given in Table 1. In order to elucidate the role played by the $-\mathrm{NO}_{2}$ group at position $\mathrm{C}-2$ of the acridone ring, the lipophilicity data of 1-9. Substitution of hydrogen by nitro group in position C-2 of the acridone ring and alkyl side chain with different secondary amino group resulted in a slight enhancement in the $\log _{10} P$ values. 
Additionally, it is speculated that the acridone nucleus with nitro group at position C-2 may exhibit higher affinity for membranes or are more readily taken up into the cells than that with hydrogen atoms. Compound 6 with $\log _{10} P$ (4.06-4.62) showed maximum binding of DNA. Therefore the degree of lipophilicity of each drug would seem to be important, but it is not the sole determinant for cytotoxicity of acridone derivatives.

\section{DNA-binding properties}

The DNA-binding properties of the compounds 2-9 were studied by monitoring the changes in the UV-Visible absorption spectra of the acridone derivatives upon addition of CT-DNA. In the range from 200-300 all acridone derivatives exhibited strong absorption peaks. Progressive addition of DNA led to strong hypochromism in the absorption intensities in all the compounds studied. The percentage hypochromism were found to be 58.46, 52.66, $30,36.5,43.84,34.33$ and 71.26.The Fig.1 shows the representative absorption spectrum of the compound $7(15 \mu \mathrm{M})$ in presence of increasing concentration of CT-DNA (0$100 \mu \mathrm{M})$. The Fig. 2 shows Half-reciprocal plot for binding of 7 with CT DNA. The compound exhibited the similar absorption spectra pertaining to the chromophore but with the hypochromicity and isobastic point depending on the alkyl amino side chains. These results were consistant with the previous reports on the absorption titration of acridone derivatives and the hypochromicity of acridones in the presence of DNA is believed to be a result of their intercalation with the DNA.

The selection of ionic strength $(150 \mathrm{mM} \mathrm{NaCl})$ in the absorption titration experiment was mainly based on the avoidance of DNA deposition in all drug solution $(15 \mu \mathrm{M})$. The Table.2 summarizes the DNA-binding constants and related properties of acridones after intercalation with CT-DNA. The relative binding affinities as indicated by the binding constant $\mathrm{K}_{\mathrm{i}}$ were in the order of $7>8>6>5>3>9>2>4$. Among the derivatives synthesized compound 7 and 8 showed strong DNA-binding affinity. However, a highest binding affinity and cytotoxic activity were observed for compound 7 bearing planar tricyclic ring with electron withdrawing nitro groups, linked with butyl morpholine side chain. There is a considerable shift in the absorption wavelenght was observed when drug binds with DNA

\section{CONCLUSION}

The new acridone analogues derived from acridone containing secondary amino group at the teminal end of alkyl chain have been showed their strong DNA binding ability through intercalation using CT DNA. In particular the effect is more pronounced with butyl side chain compare to propane chain. Comparision of the derivatives for their ability to bind with DNA revealed that they largely follow the order $\mathrm{N}^{10}$-butyl side chain more than $\mathrm{N}^{10}$-propyl side chain. The substitution of hydrogen by $\mathrm{NO}_{2}$ increased their ability to bind to DNA. Careful examination of the results revealed that the nitro butyl derivatives have higher activity than nitro propyl derivatives. With respect to these observations, we concluded that this series could be developed as a promosing cytotoxic agents as DNA intercalators

\section{ACKNOWLEDGEMENT}

Thanks AAGCPA (American Association of Government College of Pharmacy) for the STAR award(Sri Subbaraya setty Teacher and Research Students Award in Pharmaceutical Sciences). Authors thanks to IISc bengaluru, for the NMR data and Manasagangotri for the Mass analysis. Thanks to the principal of Government college of Pharmacy, Bengaluru, for providing the necessary facilities. 
Table 1: Lipophilicity values of different $\mathrm{N}$-substituted Acridone Derivatives<smiles>[R]n1c2ccccc2c(=O)c2cc([N+](=O)[O-])ccc21</smiles>

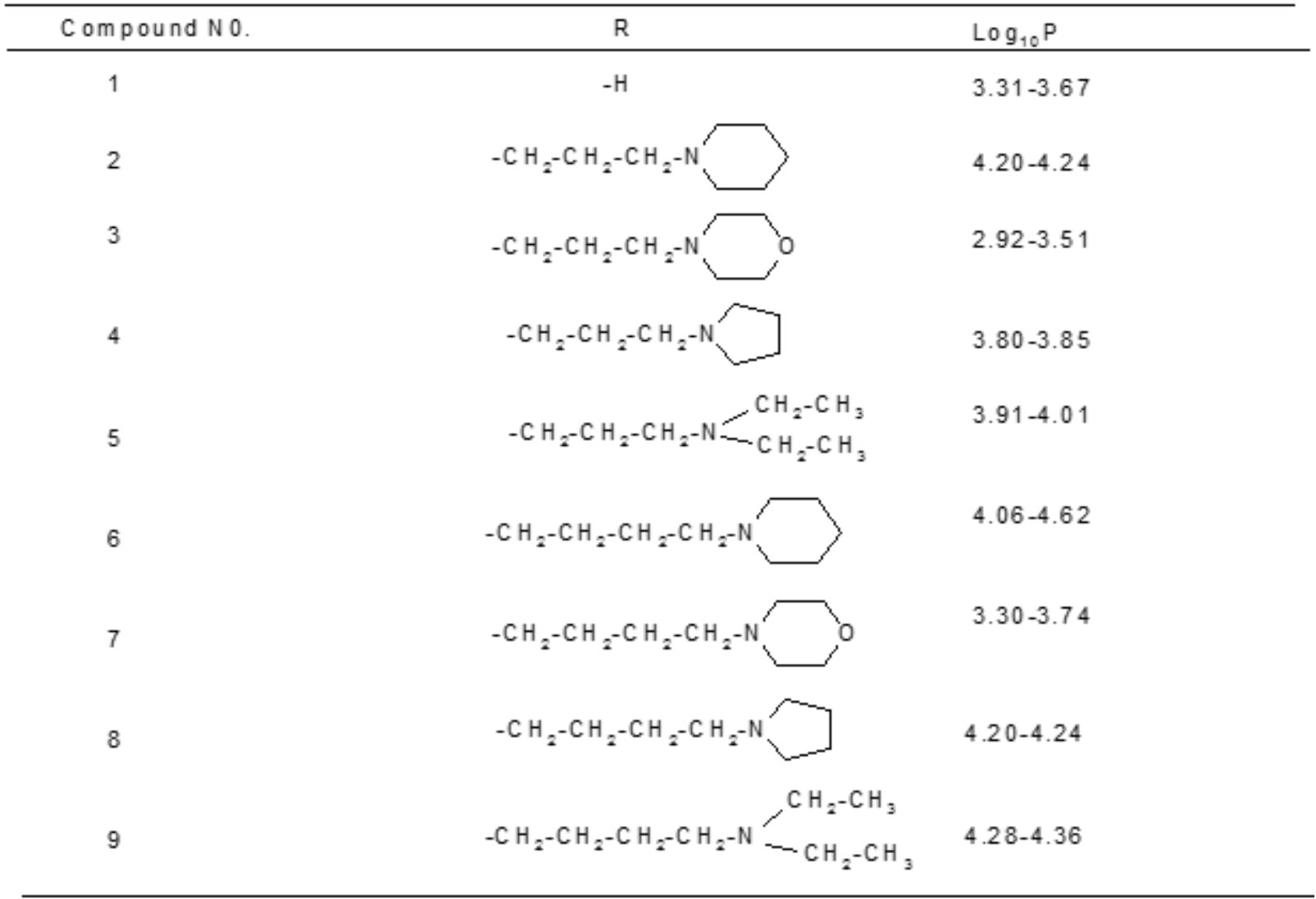

Lipophilicity was determined using the ALOGPs Software

Table 2: Binding constant $\left(\mathrm{K}_{\mathrm{i}}\right)$ and photometric properties of acridones in contact with CT-DNA

\begin{tabular}{|c|c|c|c|c|}
\hline Compound & $\mathrm{K}_{\mathrm{i}}\left(\times 10 \times \mathrm{M}^{-1}\right)$ & $\begin{array}{c}\Lambda \max \\
(\mathrm{nm})\end{array}$ & $\begin{array}{c}\text { shift in } \\
\lambda \max \end{array}$ & $\begin{array}{c}\text { Hypochromicity } \\
(\%)\end{array}$ \\
\hline 2 & 0.592 & 238 & 239 & 58.46 \\
\hline 3 & 1.17 & 238 & 240 & 52.66 \\
\hline 4 & 0.49 & 201 & - & 30 \\
\hline 5 & 1.178 & 234 & 237 & 64.28 \\
\hline 6 & 1.35 & 238 & 240.20 & 43.84 \\
\hline 7 & 1.92 & 238 & 241.20 & 34.33 \\
\hline 8 & 1.5 & 238 & 239.20 & 64.4 \\
\hline 9 & 0.646 & 274 & - & 71.26 \\
\hline
\end{tabular}




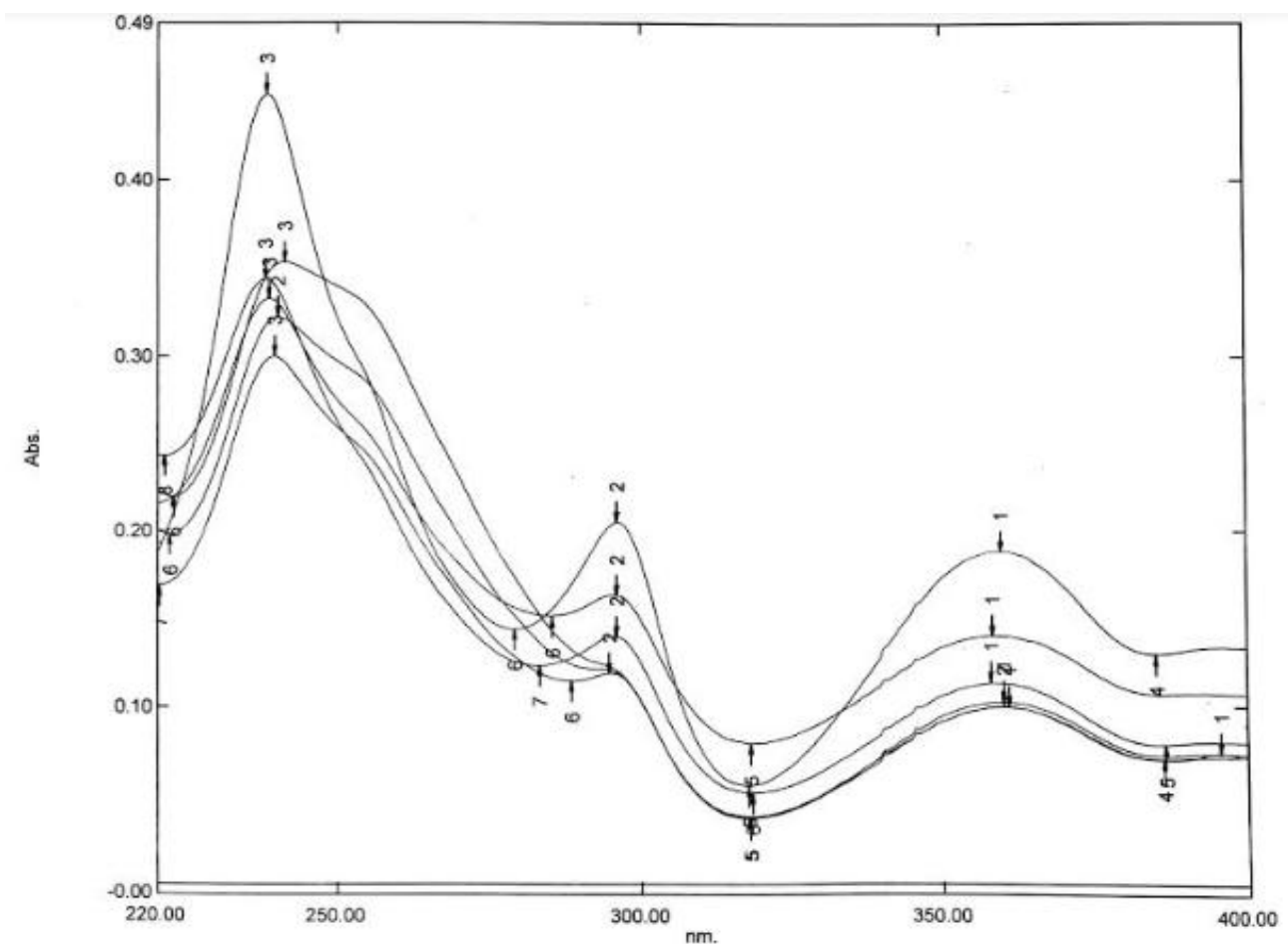

Fig. 1: Absorption titration of 7 at $15 \mu \mathrm{m}$ in $20 \mathrm{mM}$ sodium phosphate buffer (PH 6.5) with $150 \mathrm{mM} \mathrm{NaCl}$ at Increasing CT DNA concentration

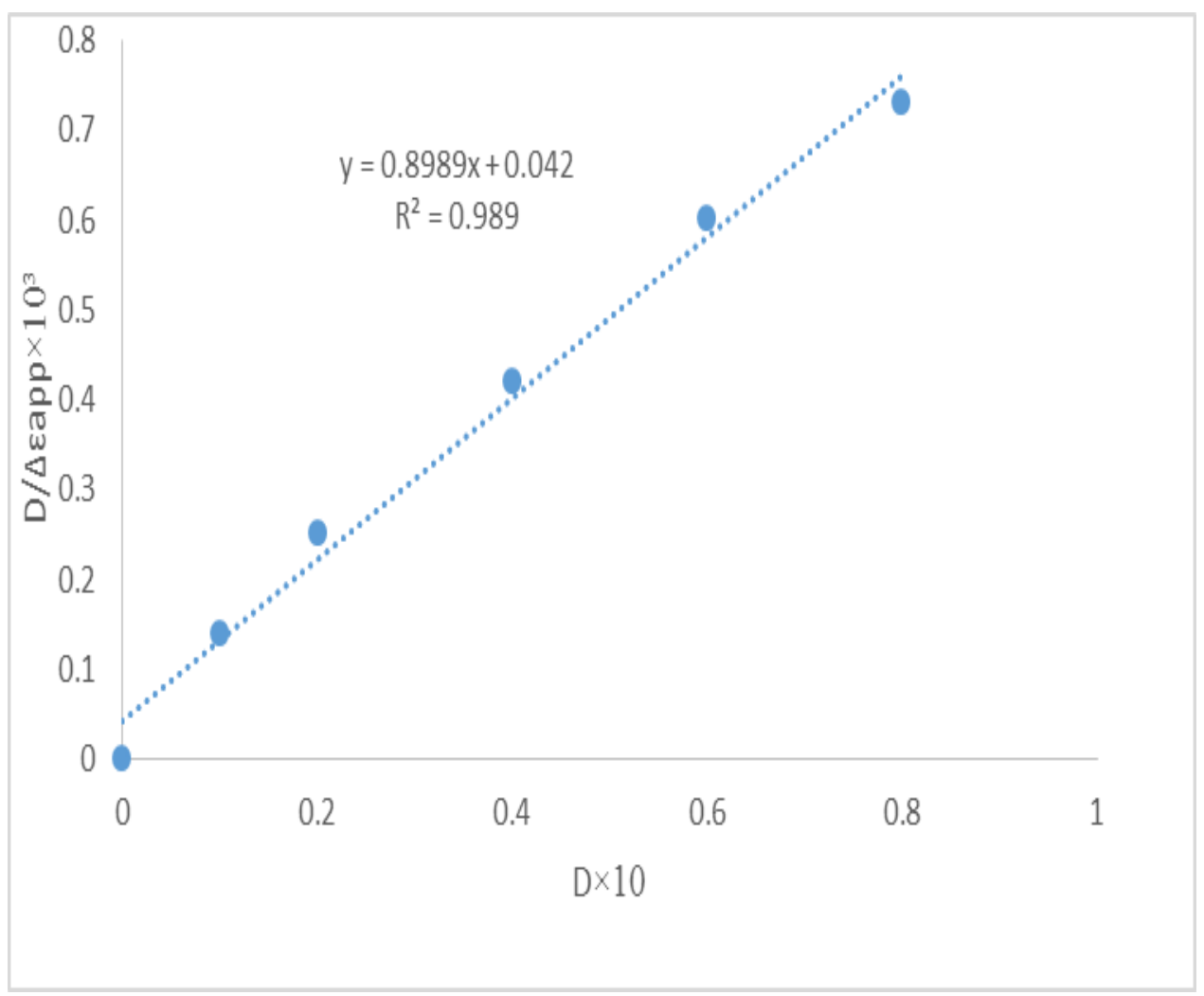

Fig. 2: Half-reciprocal plot for binding of 7 with CT DNA 


\section{REFERENCES}

1. Kamal A, Srinivas O, Ramulu P, Ramesh $G$ and Kumar PP. Synthesis of C8-linked pyrrolo [2, 1-c][1, 4] benzodiazepineacridone/acridine hybrids as potential DNA-binding agents. Bioorg Med Chem Lett. 2004;14(15):4107-11.

2. Bhattacharya $S$ and Thomas M. DNA binding properties of some cationic acridine derivatives. J Indian Chem Soc. 1998;75(10-12):716-24.

3. Brana MF, Cacho M, Gradillas A, Pascual-Teresa BD and Ramos A. Intercalators as anticancer drugs. Curr Pharm Des. 2001;7(17):1745-80.

4. Murahari M, Prakash KV, Peters GJ and Mayur YC. Acridone-Pyrimidine hybridsdesign, synthesis, cytotoxic studies in resistant and sensitive cancer cells and molecular docking studies. Eur J Med Chem. 2017;139:961-81.

5. Murahari M, Kharkar PS, Lonikar $\mathrm{N}$ and Mayur CY. Design, synthesis, biological evaluation, molecular docking and QSAR studies of 2,4-dimethyl acridones as anticancer agents. Eur J Med Chem. 2017;130:154-70.

6. Amareswararao M, Babu YR, Himabindhu $\mathrm{J}$ and Rajendra Prasad VVS. Synthesis of nitric oxide donating acridone derivatives as cytotoxic agents in cancer. Der Pharma Chemica. 2016;8(4):391-398.

7. Rajendra Prasad VVS, Reddy GD, Kathmann L, Amareswararao $M$ and Peters GJ. Nitric oxide releasing acridone carboxamide derivatives as reverters of doxorubicin resistance in MCF7/DX Cancer cells. Bioorg Chem. 2016;64:51-8.

8. Thimmaiah K, Ugarkar AG, Martis EF, Shaikh MS, Coutinho EC and Yergeri MC. DRUG-DNA interaction studies of Acridone-based derivatives. 2015;34(5):309-31.

9. Gupta SK and Baboo P. Synthesis and Antimicrobial activity of novel $\mathrm{N}^{10}$-Alkyl substituted acridine-9-one derivatives. IJRDPL. 2015Dec-Jan;4(1):1379-1385.

10. Babu YR, Bhagavanraju M, Reddy GD, Peters GJ and Prasad VVSR. Design and Synthesis of Quinazoline Tagged Acridones as Cytotoxic Agents and Their Effects on EGFR Tyrosine Kinase. Arch Pharm. 2014;347(9):624-634.
11. Babu YR, Mantripragada, Bhagavanraju and Babu VJ. Design and Synthesis of 2,4-dichloro N10-substituted acridones as cytotoxic agents effective against sensitive and resistant cancer cell lines. Int J pharm pharm sci. 2013;5(4):695700.

12. Prasad VVSR, Peters GJ, Lemos C, Kathmann L and Mayur YC. Cytotoxic studies of some novel fluoro acridone derivatives against sensitive and relative cancer cell lines and their mechanistic studies. Eur J Med Chem. 2011;43(4):217-24.

13. Prasad VVSR, Rao JV, Giri RS, Sathish NK, Kumar SMS and Mayur YC. Chloroacridone derivatives as cytotoxic agents active on multidrug-resistant cell lines and their duplex DNA complex studies by electrospray ionization mass spectroscopy. Chem Biol Interact. 2008;176(2-3):212-9.

14. Sathish NK, Gopkumar P, Prasad VVSR, Kumar SMS and Mayur YC. Synthesis, chemical characterization of novel 1,3dimethyl acridones as cytotoxic agents, and their DNA binding studies. Med Chem Res. 2010;19(7):674-89.

15. Mayur YC, Zaheeruddin, Peters GJ, Lemos C, Kathmann L and Prasad VVSR. Synthesis of 2-Fluoro $\mathrm{N}^{10}$-Substituted Acridones and Their Cytotoxic Studies in Sensitive and Resistant Cancer Cell Lines and Their Intercalation Studies. ChemInform. 2009;342(11):640-50.

16. Sathish NK and Raghavendra NM. InVitro and In-Vivo Antitumor activity of 1,3diacetoxy acridones against Ehrlich Ascites Carcinoma. Asian J Pharm Cli Res. 2010;3(4).

17. Sathish NK, Prasad VVSR, Raghavendra NM, Kumar SMS and Mayur YC. Synthesis of novel 1,3-diacetoxyacridones as cytotoxic agents and their DNA-binding studies. Sci Pharm. 2008;77(1):19-32.

18. Mayur YC, Gouda M, Gopinath VS, Kumar SMS and Prasad VVSR. Synthesis and Chemical Characterization of $\mathrm{N}^{10}$-Substituted Acridones as Reverses of Multidrug Resistance in Cancer Cells. Lett Drug Des Discov. 2007;4(5):327-35. 